\title{
Late Cretaceous and Paleogene tectonic evolution of the North Pacific Ocean
}

\author{
David K. Rea ${ }^{1}$ and John M. Dixon ${ }^{2}$ \\ 1 Oceanography Program, Department of Atmospheric and Oceanic Science, University of Michigan, Ann Arbor, MI 48109 (U.S.A.) \\ 2 Department of Geological Sciences, Queen's University, Kingston, Ont. K7L 3N6 (Canada)
}

Received March 24, 1983

Revised version received July 11, 1983

\begin{abstract}
The Late Cretaceous history of the northern Pacific Ocean has not been adequately deciphered, largely because a major plate reorganization occurred during the Cretaceous magnetic quiet interval. Using primary data to reconstruct plate motions from fracture zone trends and Late Cretaceous seafloor spreading magnetic anomalies allows formulation of a reasonable sequence of events that accounts for all the geologic features of that region, especially the Emperor and Chinook troughs. The primary event in our reconstruction is the subduction of the old northwest Pacific triple junction. New relative plate motions imposed by formation of convergent boundaries along both the northern Pacific and Farallon plates caused the Farallon plate to crack. This subdivision occurred $82 \mathrm{~m}$.y. ago and resulted in the formation of the Kula and Chinook plates. The Chinook plate was bounded on the north by the Chinook-Kula ridge, the western arm of the Great Magnetic Bight, on the west by the southern Emperor trough, a slowly spreading rift valley, on the south by the Mendocino transform, and on the east by the Chinook-Farallon ridge. The northern Emperor trough formed the initial western boundary of the Kula plate. From 82 m.y. ago to $50 \mathrm{~m} . \mathrm{y}$. ago this configuration was stable: the Chinook plate expanded, the Chinook-Kula ridge migrated north, and the Kula plate was subducted. With the subduction of this ridge, the Chinook plate adhered to the Pacific plate and the Pacific-Farallon ridge became the north-south-trending feature reflected by anomalies 22 and younger.

This reconstruction obviates the awkward Late Cretaceous shifting of triple junctions found in other proposed histories and provides reasonable explanations for the several structural features of the region. To achieve closure of vector triangles representing the relative Late Cretaceous plate motions some extension must occur, presumably across the eastern Mendocino fracture zone, between the northern and southern portions of the Farallon plate. These two plates apparently were independent units between 105 and $50 \mathrm{~m} . \mathrm{y}$. ago; the initiation and cessation of rapid North Farallon-North American convergence 82 and $50 \mathrm{~m}$.y. ago may have determined the nature and duration of the Laramide orogeny.
\end{abstract}

\section{Introduction}

During Late Cretaceous time the tectonic regime of the North Pacific Ocean underwent a change from the system of spreading centers that produced the Phoenix, Hawaiian, and Japanese magnetic lineations of the west Pacific to that which produced the Late Cretaceous and Cenozoic anomaly pattern in the north and east Pacific. The transition happened during the time of unchang- ing magnetic polarity of the earth's field in the latter portion of the Cretaceous and thus is not recorded by magnetic anomalies. The remaining clues to the nature of the Late Cretaceous tectonic transition are the structural features of the North Pacific seafloor. Of these features, which include Hess Rise and the Surveyor, Mendocino, Pioneer, and Murray fracture zones, the tectonic significance of the Chinook and Emperor troughs has remained particularly enigmatic (Fig. 1). 


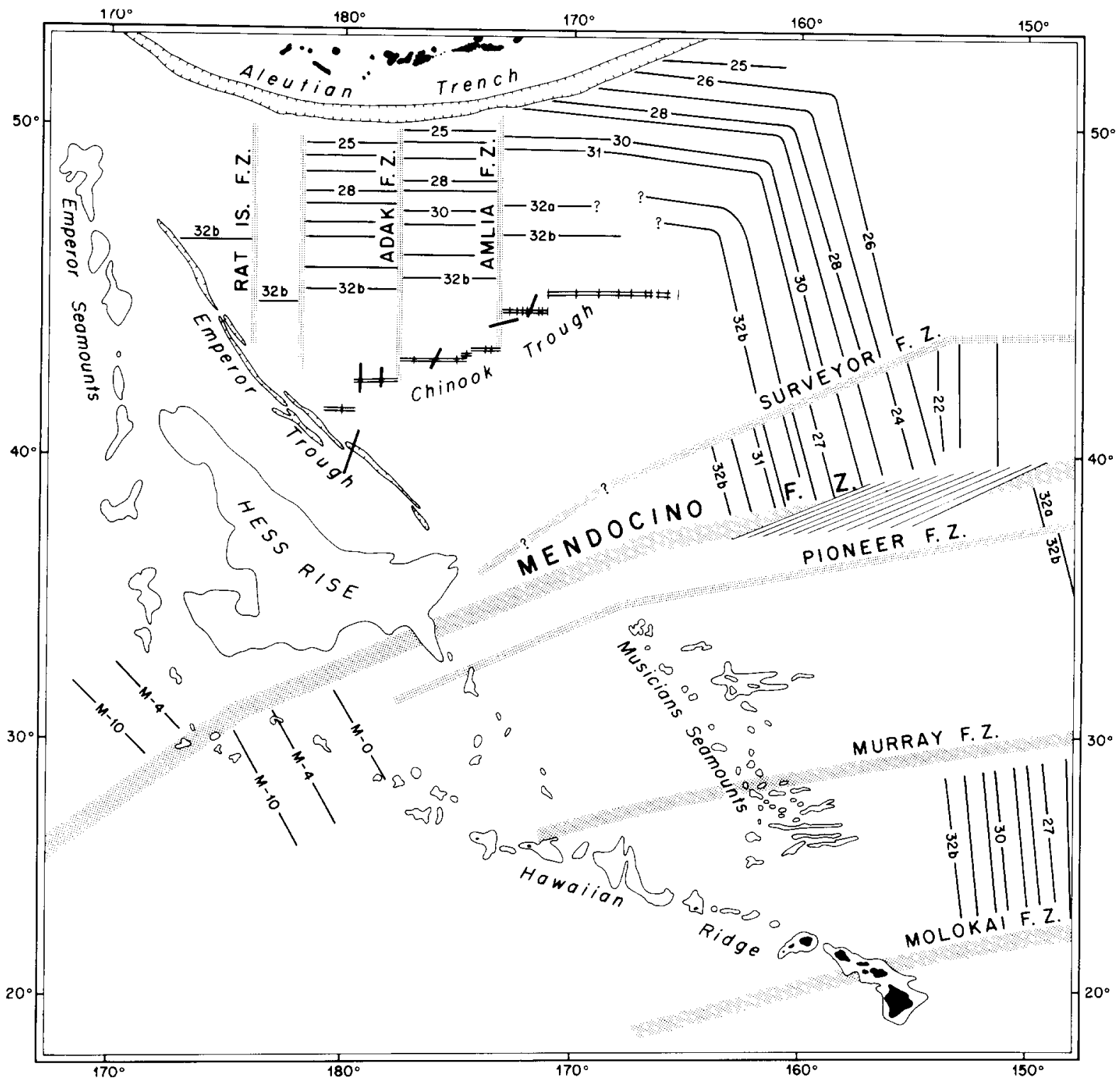

Fig. 1. Geologic features of the North Pacific Ocean. Fracture zones are shaded and linear magnetic anomalies numbered according to conventional schemes. Light lines across the Chinook trough are the NOAA crossings shown in Figs. 3 and 4 . Heavy lines represent data from 1982 cruise of the "S.P. Lee" and shown in Figs. 2, 5, and 6. Map compiled from data originally presented in references 6, $8,11,17,18,23,30$, and 41 .

\subsection{Prior work}

During the mid to late 1960 's the magnetic anomalies originally delineated by Raff and Mason [1] were mapped west to $180^{\circ}$ on the basis of data collected by Lamont-Doherty Geological Observatory and by the U.S. Coast and Geodetic Survey SEAMAP project. That effort revealed the Great Magnetic Bight [2,3] and the east-westtrending anomalies south of the Aleutian trench 
[4-7]. Those anomalies are bounded on the west and south by the Emperor and Chinook troughs, respectively [8]. Anomaly patterns in the northeastern Pacific were compiled by Pitman and Hayes [9], Atwater and Menard [10], Malahoff and Handschumacher [11], and Naugler and Wageman [12]. The large fracture zones of the eastern Pacific [13-15] were mapped to the western extent of their geophysical signature (Molokai, Murray, Surveyor) or to $180^{\circ}$ (Mendocino, Pioneer) by Malahoff and Woollard [16], Naugler and Erickson [17], and Rea [18]. The Emperor trough was first described by Erickson et al. [19]. By late 1970 the features that will most concern us here had all been mapped and described in the literature (Fig. 1).

The Early Cretaceous magnetic anomalies of the western Pacific were outlined during the late 1960 's and early 1970's [7,20,21], and these formed the basis for proposals of the tectonic evolution of that area [22-24]. In these reconstructions the Early Cretaceous western Pacific was characterized by a triple junction from which extended a southerly trending ridge system separating the Pacific and Farallon plates, a westerly trending ridge system separating the Pacific and Kula plates, and a northeasterly trending ridge system separating the Kula and Farallon plates. The Emperor trough was generally considered to be a transform fault along the Pacific-Kula boundary and the site of the southerly shift of the Pacific-Kula-Farallon triple junction [24].

More recently two papers have returned to the complexities of the Chinook-Emperor trough region. Farrar and Dixon [25] suggested that the Emperor trough is part of a long northwest-southeast wrench fault system extending south through the Line Islands. The proposed fault was considered to be active during early Tertiary time and its presumed $1700 \mathrm{~km}$ of dextral offset explained both the southerly offset of the mid-Cretaceous triple junction and some apparent discrepancies in paleolatitude between the eastern and western parts of the Pacific plate. This hypothesis also predicts that the seafloor between Hess Rise and the Emperor trough was generated by early Tertiary seafloor spreading from a NE-SW-trending ridge. During 1982 the R/V "S.P. Lee" ran a $115-\mathrm{km}$ long trackline along course $325^{\circ}$ in an attempt to find such an anomaly pattern but did not. This lack of predicted magnetic anomalies, the Cretaceous age of the Mid-Pacific mountains and the Line Islands [26] along the proposed wrench-fault, the lack of offset of orthogonal features such as the Mendocino fracture zone [18] and new evidence suggesting little or no shift in paleolatitude across the Emperor trough [27] all mitigate against the hypothesis of Farrar and Dixon [25].

Woods and Davies [28] have amplified the idea originally presented by Erickson et al. [29] and discussed by Rea [18] that the Chinook trough is the lithospheric scar marking the site where north-south seafloor spreading began south of the Aleutian trench during Late Cretaceous time. They also suggested that the Chinook feature was originally a fracture zone generated at the PacificFarallon plate boundary, like the Mendocino [28].

\subsection{Prior problems and the present effort}

The efforts to decipher the Late Cretaceous history of the north central Pacific generally suffer from one or both of the following difficulties. Most of the proposed sequences either ignore the Emperor trough or require both the Emperor trough, which trends $323^{\circ}$, and the fracture zones south of the Aleutian trench, that trend northsouth, to represent Pacific-Kula relative motion (Fig. 1). The second problem, and one that may have resulted in various misinterpretations, is that the standard compilations of bathymetric [30] and magnetic anomaly $[31,32]$ data used by marine geologists, although of great overall value, contain a few inaccuracies. For example, the Chinook trough is not a continuous feature parallel and similar to the Mendocino fracture zone as presumed by Woods and Davies [28], but it is a series of six east-west-trending features arranged in an en-echelon pattern (Fig. 1) and thus bears no resemblance to the fracture zones that were formed along the Pacific-Farallon plate boundary.

In this paper we attempt to use only the primary data pertinent to the features we discuss, the Chinook and Emperor troughs, the North Pacific fracture zones, and the magnetic anomaly pattern. We were able to augment the extant data with a brief survey of the Emperor-Chinook region dur- 
ing a cruise of the $R / V$ "S.P. Lee" during the summer of 1982. Our data compilation presented here, especially the information on fracture zone trends, constrains past plate motions and allows us to construct a tectonic history of the North Pacific from about 118 m.y. ago, the approximate age of anomaly $\mathrm{M}-0$, to $50 \mathrm{~m} . \mathrm{y}$. ago, the time of subduction of the Kula ridge (anomaly 22, time scale of Cox in Harland et al. [33]).

\section{North Pacific geophysical data}

\subsection{Emperor trough}

The Emperor trough [19] is an approximately linear feature that extends north-northwest from $37^{\circ} \mathrm{N}, 176^{\circ} \mathrm{W}$ to about $49^{\circ} \mathrm{N}, 170^{\circ} \mathrm{E}$, a distance of $1750 \mathrm{~km}$. The deep trough, reaching $1000-1500 \mathrm{~m}$ below regional base level and with $2000-2500 \mathrm{~m}$ of relief, occurs in the central portion of a 200-km-wide zone of blocky, faulted topography. Erickson et al. [19] recognized that: the Chinook trough and linear east-west-trending magnetic anomalies north of it do not extend west of the Emperor trough; the northern and southern portions of the trough have different trends, $322^{\circ}$ and $310^{\circ}$, respectively, and may have somewhat different morphology; and that the Emperor trough is the likely western margin of the Kula plate, but, if it were a tranform fault, its trend would be hard to reconcile with the north-south transform faults lying to the east.
A few additions have been made to our information about the Emperor trough since the initial description. An earthquake along the northern portion of the trough, at $44.8^{\circ} \mathrm{N}, 174.6^{\circ} \mathrm{E}$, shows reverse faulting, east side up, along a plane parallel to the trough axis [34]. The chemistry of rocks dredged from the Emperor trough indicates that it is not a subduction-zone-related feature, but rather consists of mid-ocean ridge basalts [35]. Three crossings of the northern Emperor trough by the "Glomar Challenger" [36] and the "S.P. Lee" [37] show it to be quite deep, about $7300 \mathrm{~m}$, at $45^{\circ} \mathrm{N}$ (one crossing), but less so, $6275 \mathrm{~m}$, at about $46.8^{\circ} \mathrm{N}$ (two crossings). Our crossing of the southern Emperor trough at $41^{\circ} \mathrm{N}$ shows a central deep of 7575 $\mathrm{m}$ (Fig. 2); a crossing at $39.4^{\circ} \mathrm{N}$ from the Vema-20 cruise shows a greatest depth of about $7000 \mathrm{~m}$ (shown in Vallier et al. [38]).

These crossings confirm that the maximum depth of the Emperor trough becomes roughly $1000 \mathrm{~m}$ shallower north of about $46^{\circ} \mathrm{N}$, as suggested by the data presented by Erickson et al. [19], and show that the faulted blocks which parallel the feature are tilted such that their steep slopes face the deepest trough.

\subsection{Chinook trough}

The Chinook trough [14] was originally outlined by the 1956 Chinook Expedition of the Scripps Institution of Oceanography. Data from the NOAA SEAMAP surveys [29] (Fig. 3) and a later research cruise of the "Oceanographer" [39] (Fig.

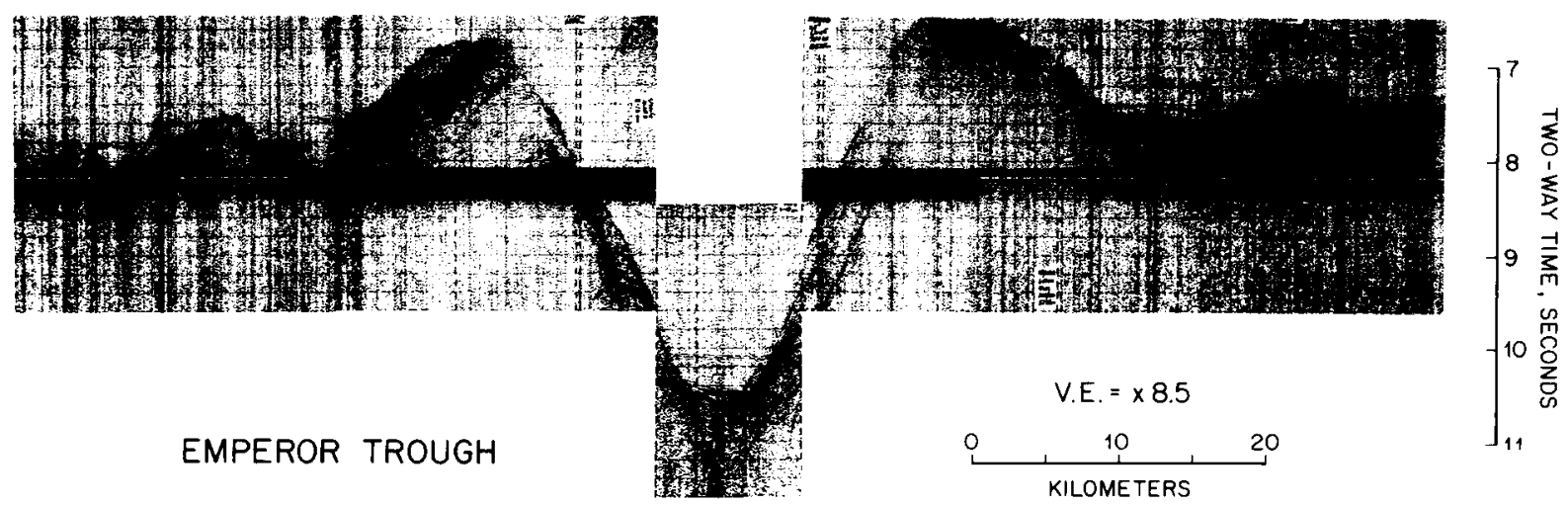

Fig. 2. Seismic-reflection profile of the "S.P. Lee" across the Emperor trough at $40.2^{\circ} \mathrm{N}, 179.5^{\circ} \mathrm{W}$. North is to the right. Profile location in Fig. 1. 
MAGNETICS

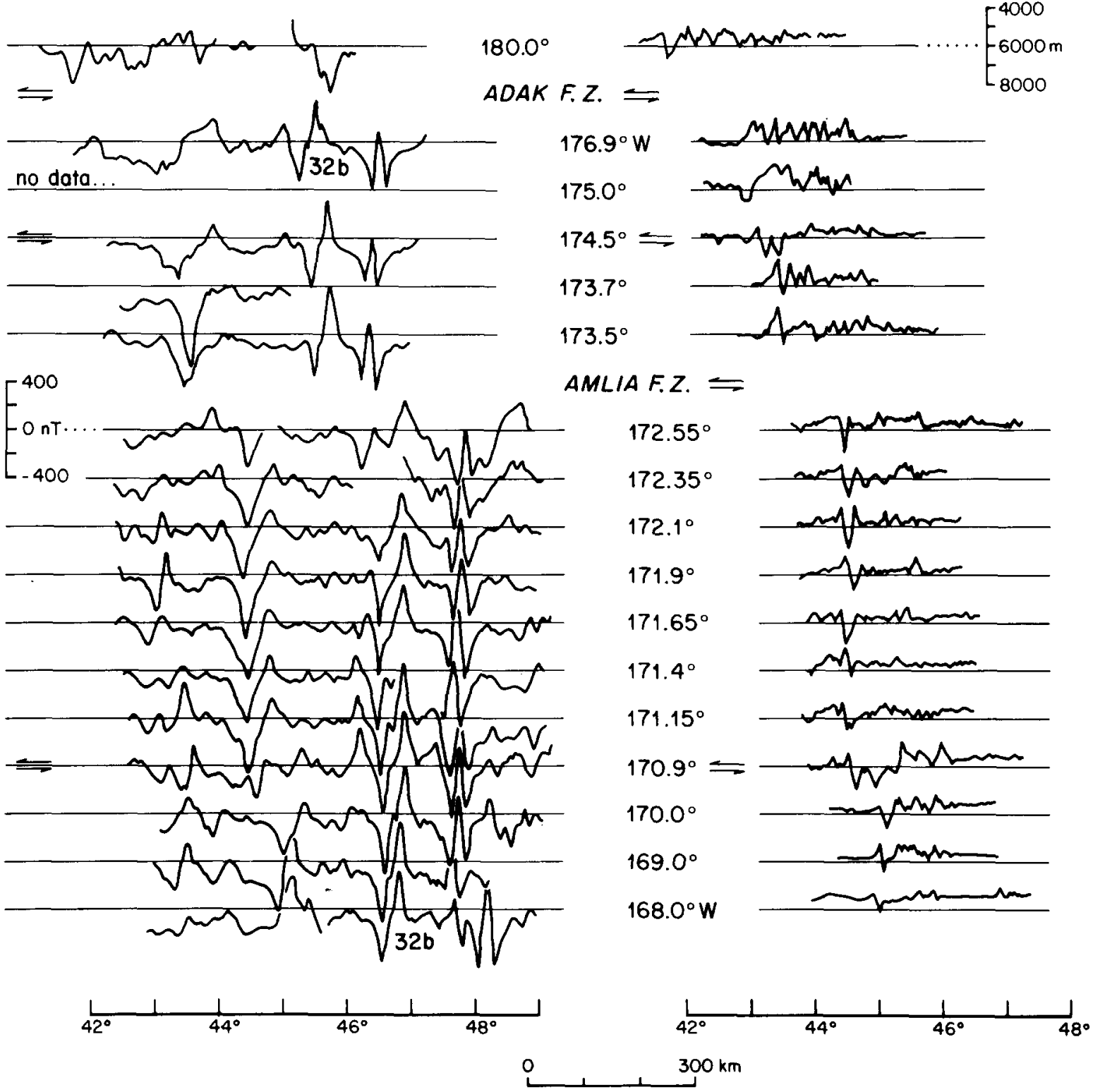

Fig. 3. Magnetic anomaly and bathymetric data from NOAA SEAMAP surveys across the Chinook trough. North is to the right, western profiles nearer the top. Location of trough crossings indicated by longitude (tracklines are all oriented north-south) and in Fig. 1.

4) provide 24 crossings of the Chinook zone (Fig. 1) and its presumed eastern extension. These easternmost tracklines show no bathymetric evidence of the Chinook trough east of $166.4^{\circ} \mathrm{W}$, and no magnetic evidence east of $166.0^{\circ} \mathrm{W}$ (Fig. 4). The Chinook trough proper is the prominent deep, commonly $1500-2000 \mathrm{~m}$ in relief, within the southern portion of a $150-$ to $200-\mathrm{km}$-wide zone of 


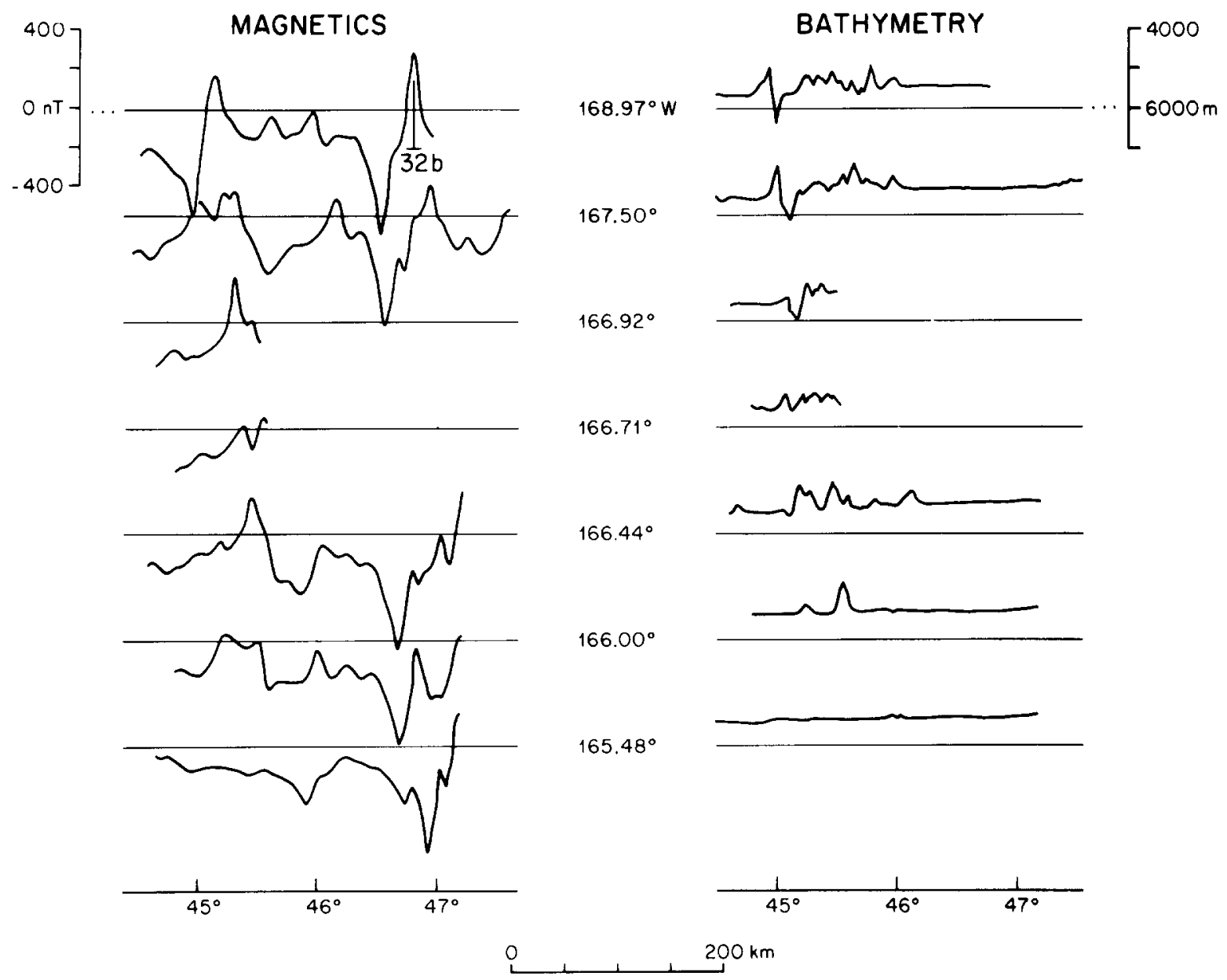

Fig. 4. Magnetic anomaly and bathymetric data from the 1971 "Oceanographer" survey to define the eastern end of the Chinook zone [39]. North is to the right, western profiles nearer the top. Location of trough crossings given by longitude (tracklines are all oriented north-south) and in Fig. 1.

blocky, disturbed topography. Both the trough and the disturbed zone occur in six discrete eastwest-trending segments (Figs. 1 and 2) offset always left-laterally. Two of the five offsets correspond to the Amlia and Adak fracture zones. Two tracklines (Fig. 3) show paired deeps in the Chinook zone that are associated with the small offsets of that feature along $170.9^{\circ} \mathrm{W}$ and $174.5^{\circ} \mathrm{W}$. The Chinook zone extends eastward from its junction with the Emperor trough at $41.5^{\circ} \mathrm{N}, 179.0^{\circ} \mathrm{E}$, to $45.2^{\circ} \mathrm{N}, 166.0^{\circ} \mathrm{W}$, exactly at the axis of the Great Magnetic Bight (Fig. 1). Fig. 5 shows four crossings of the Chinook disturbed zone acquired by the "S.P. Lee" in 1982 which typify the nature of that region.

A large-amplitude, generally $500 \mathrm{nT}$, magnetic anomaly occurs in association with the Chinook trough (Figs. 3 and 4). As this anomaly always occurs in conjunction with the deep trough, we presume it to arise from Chinook trough-associated source bodies, in a manner similar to fracture zone magnetic anomalies [40], rather than representing anomaly 33 . To the north, anomalies of the well known Late Cretaceous/Cenozoic reversal sequence trend east-west between the Chinook disturbed zone and the Aleutian trench. South of the 

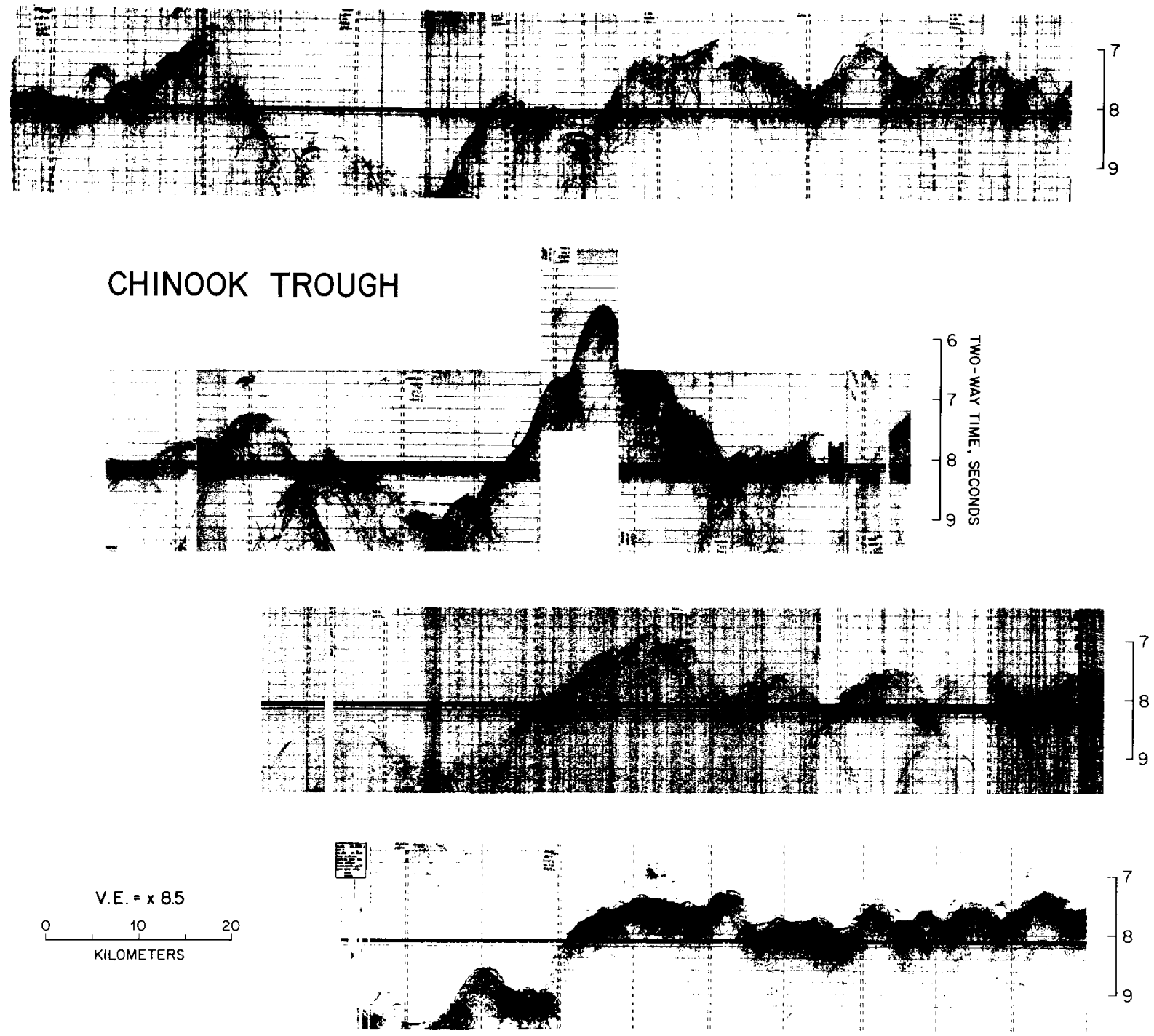

Fig. 5. Seismic-reflection profiles of the "S.P. Lee" across the Chinook trough. North is to the right, western profiles nearer the top. Profiles cross the Chinook at $179.2^{\circ} \mathrm{W}, 178.3^{\circ} \mathrm{W}, 176.0^{\circ} \mathrm{W}$, and $171.8^{\circ} \mathrm{W}$, see Fig. 1 .

Chinook trough and east of the Amlia fracture zone, lower-amplitude magnetic anomalies also trending eastwest may occur (Fig. 3a).

\subsection{Northern fracture zones}

The east-west-trending linear magnetic anomalies south of the Aleutian trench are offset by a series of north-south-trending fracture zones [4]. Two of these offsets are well mapped. The Amlia fracture zone, along $173^{\circ} \mathrm{W}$, has a left-lateral offset of $240 \mathrm{~km}$ at anomaly 30 , and $135 \mathrm{~km}$ at anomaly $32 \mathrm{~b}$ and at the Chinook trough. Topographic relief of the fracture zone is low, characteristically a linear depression interrupting the abyssal hill topography [8]. Between the offset segments of the Chinook trough, however, the Amlia shows an unusually extreme topographic expression with almost $3000 \mathrm{~m}$ of relief (Fig. 6).

The Adak fracture zone is similar bathymetri- 


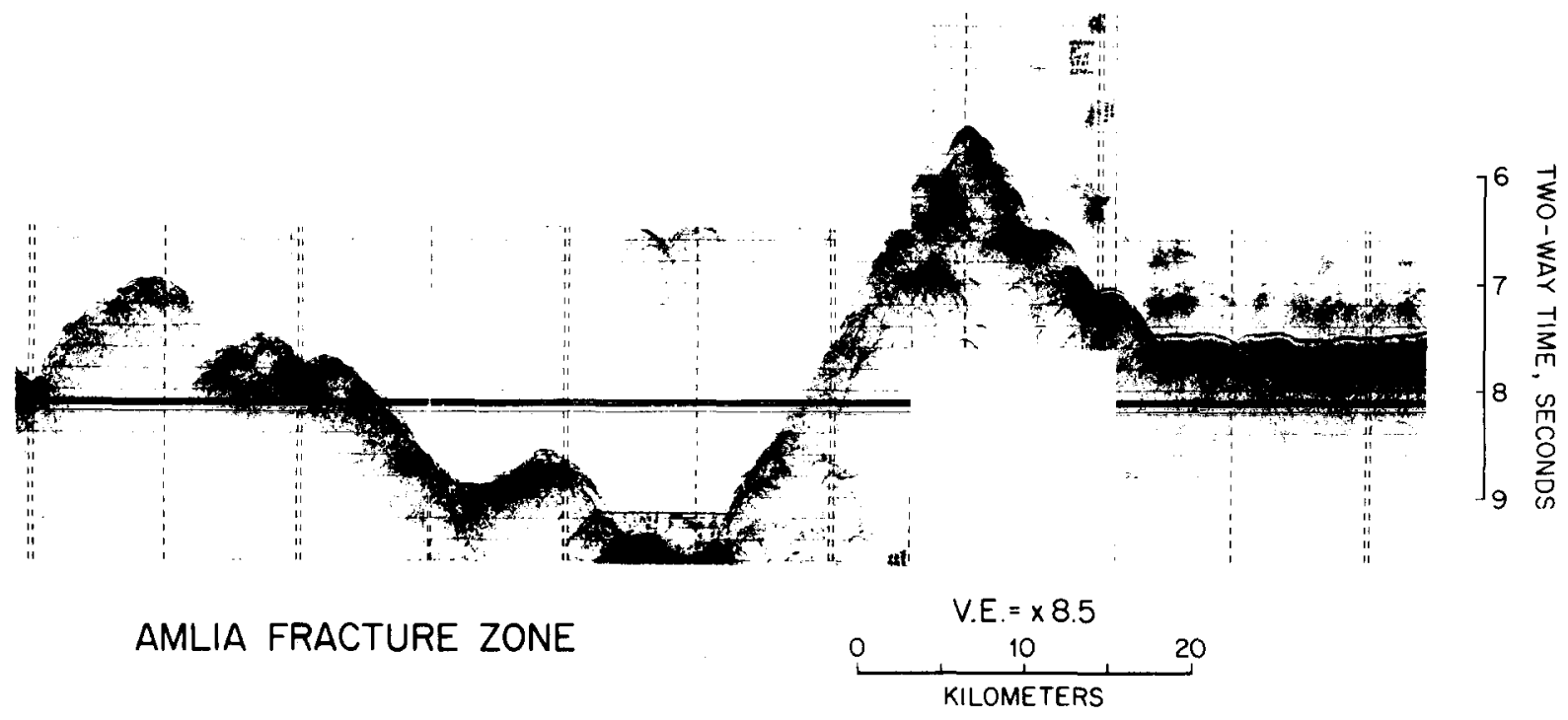

Fig. 6. Seismic-reflection profile of the "S.P. Lee" of the southern Amlia fracture zone. West is to the left. Deep trough is at $44.3^{\circ}$ N, $172.9^{\circ} \mathrm{W}$, see Fig. 1 .

cally to the northern Amlia and offsets the anomaly pattern $30 \mathrm{~km}$ left-laterally [8]. Offset of the Chinook trough across the Adak trend is $80 \mathrm{~km}$ in the same sense.

Other offsets of the magnetic anomaly pattern occur west of $180^{\circ}$ where data are sparse. Anomalies appear to be offset tens of kilometers leftlaterally near $179^{\circ} \mathrm{E}$, then dextrally by about 100 $\mathrm{km}$ at $177.5^{\circ} \mathrm{E}$ [6] (Fig. 1). This latter offset had been called informally the Rat Islands fracture zone by Erickson; we retain his terminology.

\subsection{Main North Pacific fracture zones}

By 1970 the five larger fracture zones of the north central Pacific had been mapped west to their terminations or to $180^{\circ}$ (Fig. 1). The Molokai fracture zone extends west through Molokai Island to the volcanic edifice of the Mid-Pacific Mountains [16,41,42]. Naugler and Erickson [17] mapped the Murray fracture zone west to its termination beneath the Hawaiian ridge near Laysan Island; subsequent surveys southwest of the Hawaiian ridge show that it does not extend farther west. Anomaly $32 \mathrm{~b}$ is offset $750 \mathrm{~km}$ right-laterally across the Murray.

The Mendocino-Pioneer fracture zone system was mapped west from $155^{\circ} \mathrm{W}$ to $180^{\circ}$ by Rea [18]. East of $149^{\circ} \mathrm{W}$ the Mendocino trends eastwest along about $40^{\circ} \mathrm{N}$. Between 149 and $162^{\circ} \mathrm{W}$ the Mendocino forms a broad diamond-shaped region, $300 \mathrm{~km}$ wide, with linear topographic features trending $070^{\circ}, 10^{\circ}$ oblique to the overall trend of $080^{\circ}$. This broad region is unique to the Mendocino in the North Pacific. The $080^{\circ}$ trend of the fracture zone continues west to $170^{\circ}$. Farther west it trends $20^{\circ}$ more southerly and extends at $060^{\circ}\left(240^{\circ}\right)$ across the southern edge of Hess Rise, and to the west offsets the Mesozoic anomaly pattern [22,23]. The Mendocino fracture zone, then, extends from the California coast at $40^{\circ} \mathrm{N}, 124^{\circ} \mathrm{W}$, to at least the Jurassic quiet zone at $23^{\circ} \mathrm{N}, 165^{\circ} \mathrm{E}$, a distance of about $6800 \mathrm{~km}$ - the longest linear tectonic feature on earth. Offsets across the Mendocino-Pioneer system are sinistral, approximately $350 \mathrm{~km}$ at $118 \mathrm{~m}$.y. ago (anomaly CL of Hilde et al. [23], and M-0 of more recent compilations; time scale of Cox in Harland et al. [33]) and about $1100 \mathrm{~km}$ at the time of anomaly $32 \mathrm{~b}$ (72 m.y. old, [33]).

The Surveyor fracture zone can be traced as a coherent structure west to about $170^{\circ} \mathrm{W}$ [18]. Between $170^{\circ} \mathrm{W}$ and about $153^{\circ} \mathrm{W}$ the Surveyor trends $068^{\circ}, 12^{\circ}$ from the Mendocino-Pioneer- 
Murray trends to the south. East of $153^{\circ} \mathrm{W}$ the Surveyor trends $090^{\circ}$, parallel to all the other fracture zones. West of $170^{\circ} \mathrm{W}$ the Surveyor fracture zone is represented by an ill-defined region of ridges and troughs that trend southwesterly. These western structures are not parallel to the Mendocino and terminate in the vicinity of the southern end of the Emperor trough near $37^{\circ} \mathrm{N}$, $175^{\circ} \mathrm{W}[18,23]$.

\subsection{Linear magnetic anomalies}

The linear magnetic anomalies of the north central Pacific were identified and mapped by a number of different investigators [2-12,43,44]. Most of these data were compiled onto a single map by Pitman et al. [31].

Combining the locations of the linear magnetic anomalies with a paleomagnetic time scale should result in a reasonable estimate of Late Cretaceous to early Tertiary one-flank spreading rates. Unfortunately every compilation map provides slightly different rates, and evidence for small ridge jumps, especially around the Great Magnetic Bight, complicates the calculations. To avoid some of these problems we calculated spreading rates along individual magnetic anomaly profiles. Measuring the distance between anomalies 27 and $32 \mathrm{~b}$ which have ages of 61.15 and 71.78 m.y. [33], we get the following spreading rates: 38.0 and $35.8 \mathrm{~mm} / \mathrm{yr}$ between the Adak and Amlia fracture zones, and $46.1 \mathrm{~mm} / \mathrm{yr}$ (ridge jumps) east of the Amlia fracture zone [5]; $37.1 \mathrm{~mm} / \mathrm{yr}$ north of the Surveyor fracture zone [6]; $36.9 \mathrm{~mm} / \mathrm{yr}$ between the Surveyor and Mendocino fracture zones [39]; 41.6 $\mathrm{mm} / \mathrm{yr}$ between the Pioneer and Murray fracture zones [3]; and $42.4 \mathrm{~mm} / \mathrm{yr}$ south of the Murray [11]. These data suggest that along the western edge of the early Tertiary Farallon plate the Mendocino transform divided a slower spreading, $37 \mathrm{~mm} / \mathrm{yr}$, regime to the north from a more rapidly spreading, $42 \mathrm{~mm} / \mathrm{yr}$, regime to the south.

\section{Late Cretaceous tectonic elements}

\subsection{Definition of the problems}

Four general problems concerning the genesis and significance of the tectonic features described above can be identified. We note that the Amlia-Adak fracture zones (trending $000^{\circ}$ ), Surveyor fracture zone $\left(068^{\circ}\right)$ and MendocinoPioneer system $\left(080^{\circ}\right)$ define three transform trends that co-existed for about $30 \mathrm{~m}$.y. Rigid-plate tectonics then requires the existence of four plates in this region. If the Emperor trough were an active transform fault at the same time, then five plates are necessary to explain these features. The first problem, therefore, is to identify these old plates and characterize the nature and geologic history of their boundaries.

Among the many structural features of the North Pacific the tectonic significance of the Emperor trough is the least understood; most investigators have considered it to be a fracture zone. The second problem, then, is to define the true nature of the Emperor trough.

The third problem concerns the tectonic implications of the Chinook trough, especially determining its origin and relation to both the Emperor trough and the Great Magnetic Bight. In this case, the general idea that the Chinook feature somehow denotes the onset of north-south seafloor spreading from an east-west ridge system appears valid $[28,29]$.

The fourth task is to decipher the tectonic history recorded by the geometry and extent of the large North Pacific fracture zones. What, for example, accounts for the unusual aspects of the Surveyor fracture zone west of $170^{\circ} \mathrm{W}$, the sudden termination of the Murray at $173^{\circ} \mathrm{W}$, and the diamond-shaped region along the Mendocino with topographic trends subparallel to those of the Surveyor?

\subsection{Four Pacific paleoplates}

Rigid-plate tectonic theory, when applied to the data set presented above, permits a resolution of the posed problems in plate mechanics. In our reconstructions we hold the Pacific plate fixed as the point of reference and consider the Mendocino-Pioneer fracture zone system to be a faithful representation of Pacific-Farallon relative plate motion.

From the information given in Fig. 1 and described above, it is possible to determine the plate 


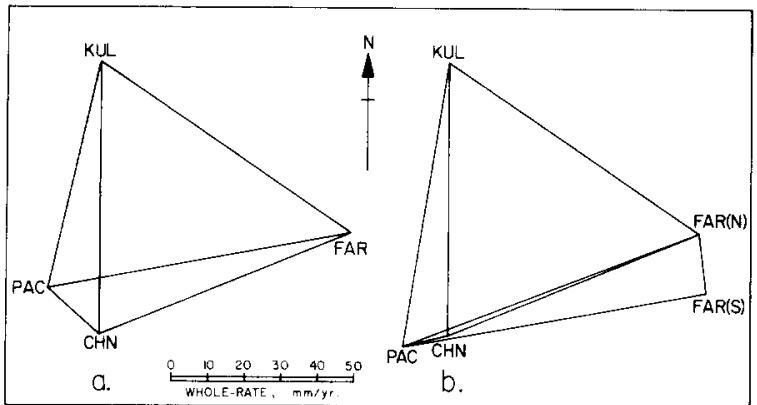

Fig. 7. Vector diagrams of Late Cretaceous/Paleogene plate motions among the Pacific (PAC), Kula (KUL), Farallon (FAR), and Chinook (CHN) plates. (a) Single Farallon plate requires Chinook-Pacific convergence across the Mendocino, strike-slip along the Emperor trough. (b) Pacific-Chinook divergence at the Emperor trough and strike-slip at the Mendocino requires a northern, FAR(N), and southern FAR(S), Farallon plate separated by a divergent boundary. See Table 1 for relative motions.

configuration in the central Pacific at the time of anomaly $32 \mathrm{~b}$, about 72 m.y. ago. The Mendocino transform is the boundary between the Pacific plate to the south and some other plate $X$ to the north. Farther north the southeast limb of the Great Magnetic Bight is the Farallon-X divergent boundary, and the Surveyor fracture zone is part of that boundary. The western limb of the bight and the Adak, Amlia and related transforms sep- arate plate $X$ from the Kula plate, which lies to the north. Plate $X$ then requires a southwestern boundary and the only plausible and obvious feature is the southern Emperor trough. The plate so described is referred to here as the Chinook plate.

\subsection{Late Cretaceous kinematics}

Pacific-Farallon and Chinook-Farallon spreading rates and directions between the times of anomalies 27 and $32 \mathrm{~b}$ are well constrained at 84 $\mathrm{mm} / \mathrm{yr}$ at $080^{\circ}$ and $74 \mathrm{~mm} / \mathrm{yr}$ at $068^{\circ}$, respectively. These values appear to require $12 \mathrm{~mm} / \mathrm{yr}$ of crustal generation along $080^{\circ}$ north of the Mendocino at the Pacific-Chinook boundary, presumably the southern Emperor trough. However, vector addition of the two better known rates and directions prescribes right-lateral strike slip motion along the Emperor trough at $132^{\circ}$ and 19 $\mathrm{mm} / \mathrm{yr}$ (Fig. $7 \mathrm{a}$ ). This would produce $600 \mathrm{~km}$ of convergence across the Mendocino fracture zone throughout the tectonic evolution proposed below.

If we apply the additional and conceptually reasonable constraint of no convergence across the Mendocino transform, opening across the Emperor trough is maintained and, importantly, the vector solution requires relative motion within the Farallon plate across the eastward extension of the

TABLE 1

Late Cretaceous relative plate motions

\begin{tabular}{|c|c|c|c|}
\hline Plate pair & Boundary feature & Azimuth & $\begin{array}{l}\text { Whole rate } \\
(\mathrm{mm} / \mathrm{yr})\end{array}$ \\
\hline PAC-FAR(S) & ridge south of Mendocino fracture zone & $080^{\circ}$ & $84^{a}$ \\
\hline FAR(N)-CHN & ridge north of Surveyor fracture zone & $068^{\circ}$ & $74^{\mathrm{a}}$ \\
\hline PAC-CHN & $\begin{array}{l}\text { southern Emperor trough } \\
\text { Mendocino fracture zone }\end{array}$ & $075^{\circ} \mathrm{b}$ & $12^{\mathrm{c}}$ \\
\hline PAC-KUL & northern Emperor trough & $009^{\circ} \mathrm{d}$ & $78^{d}$ \\
\hline CHN-KUL & $\begin{array}{l}\text { Kula ridge, Amlia fracture zone and } \\
\text { Adak fracture zone }\end{array}$ & $000^{\circ}$ & $74^{\mathrm{a}}$ \\
\hline KUL-FAR(N) & $\begin{array}{l}\text { ridge, third arm of Great } \\
\text { Magnetic Bight triple junction }\end{array}$ & $124^{\circ \mathrm{d}}$ & $82^{d}$ \\
\hline $\operatorname{PAC}-\operatorname{DAR}(\mathrm{N})$ & $\begin{array}{l}\text { diamond-shaped region of } \\
\text { Mendocino fracture zone }\end{array}$ & $069^{\circ} \mathrm{b}, \mathrm{d}$ & $86^{\mathrm{d}}$ \\
\hline FAR(N)-FAR(S) & ridge & $351^{\circ d}$ & $17^{\mathrm{d}}$ \\
\hline
\end{tabular}

${ }^{a}$ Doubled observed half-rates.

b Assumed from bathymetric trends.

c From differences in accretion rates, see text.

${ }^{d}$ Determined by vector addition, see Fig. $7 b$. 
Mendocino fracture zone. The amount of this motion is relatively insensitive to the values of Pacific-Chinook opening chosen for the Emperor trough. For a divergence rate of $12 \mathrm{~mm} / \mathrm{yr}$ at $075^{\circ}$, the relative motion between the northern and southern Farallon plates would have been 17 $\mathrm{mm} / \mathrm{yr}$ at $351^{\circ}$ (Fig. $7 \mathrm{~b}$ ).

Chinook-Kula spreading along the Adak and Amlia fracture zones was $74 \mathrm{~mm} / \mathrm{yr}$ at $000^{\circ}$. Continuing the vector summation to determine Pacific-Kula motion (Fig. 7 b) gives $78 \mathrm{~mm} / \mathrm{yr}$ at $009^{\circ}$ (Table 1).

\subsection{Emperor trough}

Our measured spreading rates and vector additions (Table 1, Fig. 7b) show that about 70 m.y. ago the Emperor trough was a slowly opening rift valley along its southern portion (Fig. 2). The northern Emperor trough represented the site where the Kula plate began to move north from the Pacific plate. Presumably this opening began as highly oblique spreading with segments reorienting to a more orthogonal ridge and transform system shortly after their initiation, allowing the northern part of the trough to become inactive. The northwesternmost segment of the Pacific-Kula plate boundary would be a $009^{\circ}$-trending, ridgetrench transform fault.

The Emperor trough is similar in structure to several other troughs that have been interpreted to be abandoned slowly- to moderately-spreading ridge axes: the Malpelo rift in the eastern Panama basin [45,46]; the Guadalupe trough [47] west of Baja; the Nova-Canton [22,48] and Magellan $[49,50]$ troughs in the western equatorial Pacific; and the Coral Sea basin [51].

\subsection{Chinook trough}

The Chinook disturbed zone represents a cracking of the old Farallon plate, forming the Chinook and Kula plates from northwestern Farallon plate. The timing of this event can be estimated by extrapolating the known seafloor spreading rate of $37 \mathrm{~mm} / \mathrm{yr}$ over the $405 \mathrm{~km}$ distance between anomaly $32 \mathrm{~b}$ and the western Chinook trough to get an age of $82 \mathrm{~m}$.y. We presume that the crack- ing event happened rapidly enough to be considered instantaneous. After initiation, ridge-transform adjustments eliminated some offsets and changed the length of others to make the system more geometrically simple. It is not clear whether the primary crack was linear and then shifted rapidly to the offset orthogonal pattern. If so, the portion of the southern Amlia fracture zone with $2700 \mathrm{~m}$ of relief (Fig. 6) may be a segment of the original break.

The Chinook trough, as the lithospheric scar denoting the inception of a new spreading center in older crust, is structurally similar to, although more extensive than, the scarps bounding the modern East Pacific Rise north of the Orozco fracture zone $[46,52]$ and between $5^{\circ} \mathrm{S}$ and $14^{\circ} \mathrm{S}$ [53], and the Hudson trough in the southeast Pacific [54].

\subsection{Mendocino fracture zone}

Between $170^{\circ} \mathrm{W}$ and $162^{\circ} \mathrm{W}$ the Mendocino is linear and trends $080^{\circ}$. This segment formed a long offset of the Pacific-Farallon ridge and, following the plate reorganization at 82 m.y. ago, constituted the Pacific-Chinook transform boundary. Eastward, from $162^{\circ} \mathrm{W}$ to $149^{\circ} \mathrm{W}$, the Mendocino fracture zone broadens into a diamond-shaped region characterized by en-echelon topographic trends striking $070^{\circ}$ [30] (Fig. 1). Here the Mendocino separated the Pacific and northern Farallon plates which shared a relative motion of approximately $86 \mathrm{~mm} / \mathrm{yr}$ at $069^{\circ}$ (Table 1 ). A series of longer transforms joined by shorter ridge segments must have accommodated this relative motion. This episode of oblique opening across the general Mendocino trend would have coincided with the age and duration of an independent Chinook plate.

East of the Chinook plate divergence between the northern and southern parts of the Farallon plate was probably across a simple spreading center that has since been subducted beneath western North America. The Eocene reorganization that resulted in $090^{\circ}$ trends along all the east Pacific fracture zones would have ended the opening across the Mendocino both east and west of the Pacific-South Farallon ridge. 


\subsection{Murray fracture zone}

The geophysical signature of the Murray fracture zone extends west to approximately $173^{\circ} \mathrm{W}$ where it terminates in the Hawaiian ridge volcanics west of Laysan Island [17]. Fracture zones commonly have as their origin a sudden change of location or jump of a seafloor spreading center. Furthermore, investigators studying the geologic history of the North Pacific have all recognized that the increase in offset along the MendocinoPioneer fracture zone system that occurred during the Late Cretaceous magnetic quiet zone required either an episode of rapid asymmetrical spreading or a large eastward jump of a portion of the Pacific-Farallon ridge [22-24,50].

The most simple sequence of events that explains the observations is an eastward jump of the northern half of the spreading center that originally extended from the Mendocino-Pioneer system southeast to the Molokai fracture zone. The ridge jump would have to occur when the Mendocino-to-Molokai axis segment reached $173^{\circ} \mathrm{W}$, the present location of the western termination of the Murray fracture zone [17,18,50]. Extrapolations (at constant spreading rate) based upon the magnetic anomaly maps of Hilde et al. [23] and the Mesozoic magnetic anomaly time scale [33] give an age of $107 \mathrm{~m} . \mathrm{y}$. for the time when the spreading center would have reached this location and the jump would have occurred. The northern half of this axis segment jumped $750 \mathrm{~km}$ to the east, forming the observed right-lateral 750 $\mathrm{km}$ offset across the Murray fracture zone and increasing the left-lateral offset across the Mendocino system.

Three observations concerning this mid-Cretaceous ridge jump bear upon the regional geology. First, the pre-jump position of the Mendocino-toMolokai axial segment coincides with the ridge extending southeast from southern Hess rise (Fig. 1) and is the same general age. Furthermore, to the north the main structural axis of Hess Rise, thought to have formed near or at a spreading center $[38,55,56]$, is offset left-laterally $350 \mathrm{~km}$ from the southeast extension, the same as the slightly older magnetic anomaly offsets across the Mendocino fracture zone.
Secondly, the post-jump spreading center position $750 \mathrm{~km}$ to the east falls about $100 \mathrm{~km}$ west of the Musicians seamounts (Fig. 1) [57] and a similar distance west of the line along which the Mendocino, Pioneer and Murray fracture zones all undergo large-scale changes in bathymetric and magnetic character as well as trend [18]. Large ridge jumps sometimes result in structural features where new spreading begins, such as the Chinook trough or the Bauer scarp on the East Pacific Rise [53] which can be up to 100 or more kilometers wide. It is possible, therefore, that the location of both the Musicians seamounts and the changes in fracture zone structural geology are related to this ridge jump. Conversely, we note that the jump distance as constrained by the fracture zone offset is about $100 \mathrm{~km}$ too small, that seamount chains have been interpreted as denoting dying spreading centers (Mathematician-Clipperton seamounts [46,52]; fossil Galapagos rise [58]) but not beginning ones, and that the Musicians seamounts may show an age progression, older to the north [59], implying a hotspot origin for them.

Finally, a 750-km eastward jump of the spreading center occurring 107 m.y. ago would be expected to have isolated some of the M-series anomalies in the Farallon crust added to the Pacific plate. However, no coherent anomaly pattern has been reported from the region from the Musicians seamounts west toward the Hawaiian ridge.

\section{Evolution of tectonic features}

The Early Cretaceous evolution of the North Pacific has been determined by Larson and Hilde and their co-workers $[22-24,60]$. We begin this narration of the middle and Late Cretaceous evolution with the plate configuration at the time of anomaly M-0, based upon the maps presented by Hilde et al. [23] (Fig. 8a). Anomaly $\mathrm{M}-0$ has been assigned an age of 118.6 m.y. [33]. A ridgeridge-ridge triple junction located in the North Pacific separates three plates, the Farallon plate to the east, the Pacific plate to the southwest, and a third plate, not the Kula plate, to the northwest. This third plate will be referred to as the Bering plate because the remaining portion of it now 
underlies the Bering Sea [61]. The Bering plate is similar in concept to the Early Cretaceous Kula plate of Hilde et al. [23,24] and to the Izanagi plate of Woods and Davies [28] but since a remnant of this old plate still exists, we prefer the geographical name. The Pacific-Farallon spreading center, of major concern here, is offset $350 \mathrm{~km}$ left-laterally along the Mendocino trend, and right-laterally, perhaps $200 \mathrm{~km}$, along another transform extending northeast from Shatsky rise and about $1000 \mathrm{~km}$ north of the Mendocino and $500 \mathrm{~km}$ south of the triple junction. Seafloor spreading before this time had been about $5 \mathrm{~cm} / \mathrm{yr}$ half-rate but appears to have slowed down and changed to a more easterly direction prior to the time of volcanic build-up at Hess rise.

By 105 m.y. ago (Fig. 8b), the triple junction had migrated north about $600 \mathrm{~km}$ (assuming constant spreading rate across Pacific-Bering ridge) and voluminous volcanic activity along the more slowly spreading Pacific-Farallon ridge had created Hess rise $[38,55,56,62]$, the location of which is controlled by damming of the ridge-related volcanic effusions at the Mendocino and Shatsky transforms. The eastward ridge jump of $750 \mathrm{~km}$ south of the Mendocino-Pioneer fracture zone system that occurred 107 m.y. ago had increased the offset across that feature and created the Murray transform and fracture zone [50]. Perhaps the Pioneer fracture zone began as a separate structure at this time as well.

The perceived slowing of spreading north of the Mendocino contrasts with apparently continuous plate separation at about $80 \mathrm{~mm} / \mathrm{yr}$ south of it, where there is $1000 \mathrm{~km}$ more of crust aged 105 to 72 m.y. than lies to the north. This discrepancy suggests either additional and identical eastward ridge jumps along all segments of the Pacific Farallon boundary south of the Mendocino fracture zone, extremely asymmetric spreading along the Pacific-Farallon and later the Chinook-Farallon ridges, or, if spreading is symmetrical, leftlateral shear of about $60 \mathrm{~mm} / \mathrm{yr}$ along the eastern Mendocino, between the northern and southern Farallon plates. We will assume this last alternative to be the case (Fig. 8 b) because it can reasonably evolve to the proposed divergent boundary between the northern and southern Farallon plates
(Fig. 7b, Table 1), and helps to explain the consequences of Farallon-America interaction.

At 83 m.y. ago the plate boundary configuration remained much the same as in mid-Cretaceous time, although the location (existence?) of the Shatsky transform is no longer apparent (Fig. $8 \mathrm{c})$. It was too far north to have been the precursor to the Chinook trough, and the Emperor trough is not offset. In Fig. 8c, 83 m.y. ago, we presume the Shatsky offset has healed, probably because of the eastward ridge jump that isolated the Hess rise entirely on the Pacific plate. At this time the Pacific-North Farallon-Bering triple junction lay about $3300 \mathrm{~km}$ northwest of the Mendocino fracture zone at the Siberian-Alaskan continental margin, and the Pacific-North Farallon divergent boundary now approximates the location of the Emperor trough. The spreading ridge south of the Mendocino continues to spread much faster than to the north, and the eastern extension of the Mendocino fracture zone is still an active leftlateral transform fault between the North and South Farallon plates.

At about 82 m.y. ago, a major alteration to the North Pacific tectonic regime occurred. The Bering-Pacific and Bering-North Farallon ridges were subducted along the Siberian-Alaskan continental margin, and subduction began along the northwestern and northern boundaries of the Pacific and North Farallon plates. The locus of subduction in the north central Pacific must have shifted south from the continental margin about this time, forming the ancestral Aleutian trench and trapping Mesozoic crust formed at the Bering-North Farallon ridge in the Bering Sea [24]. The addition of sinking slabs to the Pacific and North Farallon plates resulted in a new set of relative motions of the two plates. In response the Pacific plate began to more more northerly and the North Farallon plate separated into three fragments, the Kula plate moving north, the now smaller North Farallon plate moving east from the Pacific plate, and the enlarging Chinook plate (Fig. 8d). The new Kula plate was bounded on the southwest by an obliquely spreading ridge along the site of the former northernmost segment of the Pacific-Farallon ridge (now the northern Emperor trough), on the south by an orthogonal ridge- 

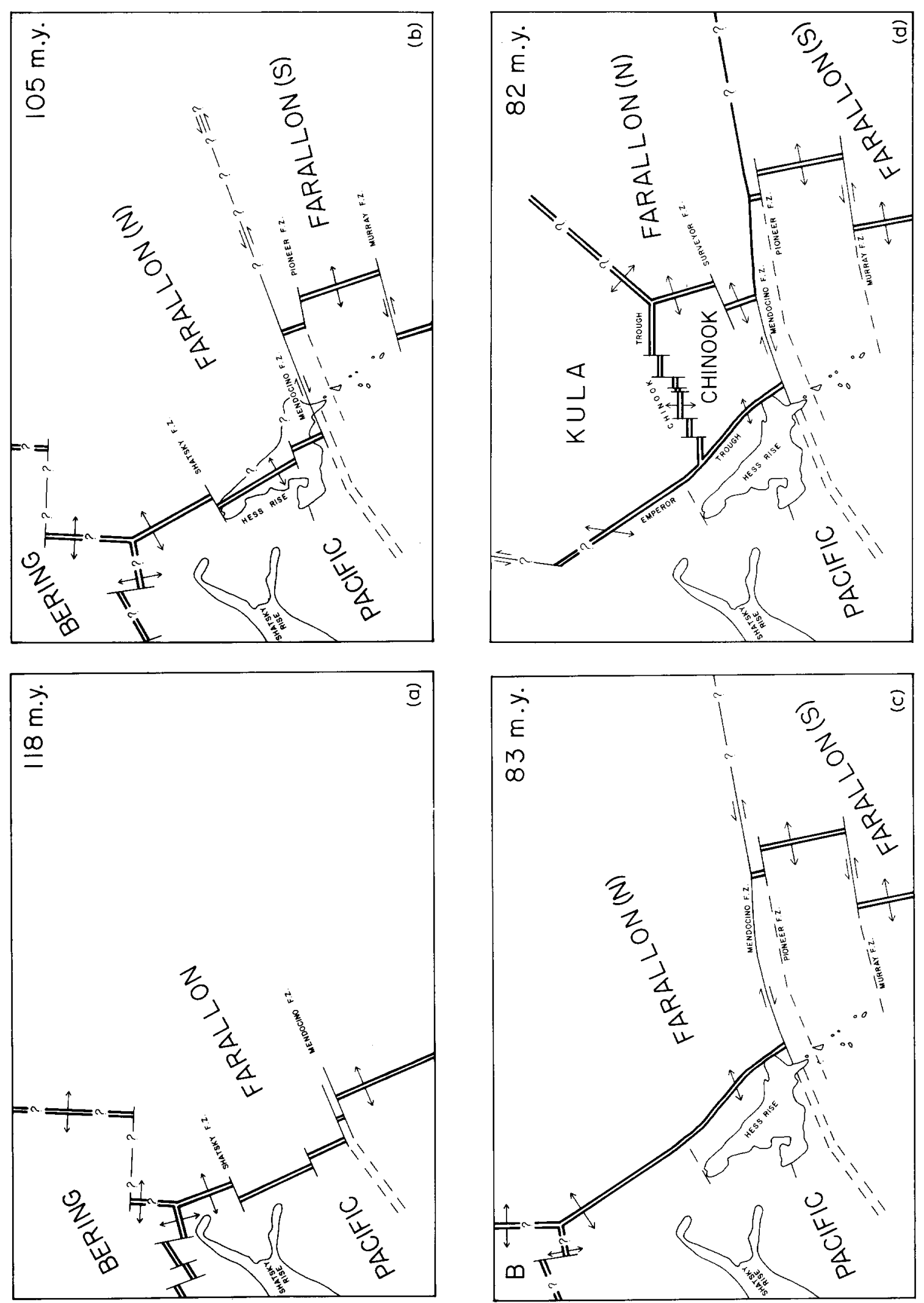




产萦

路象

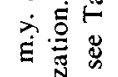

瓷

5气 总

咅产

范范

类苋

อ

政 co

宝苞

뜬조

ज㐫

苛

氙

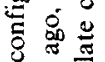

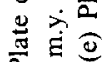

ङ

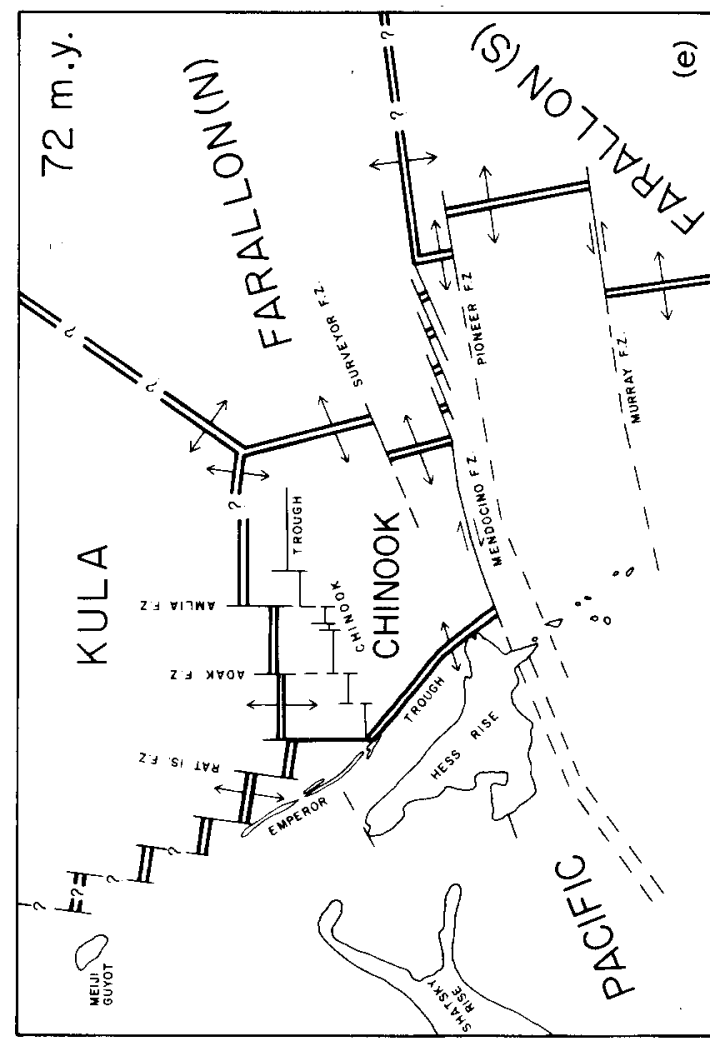

丞

宝

的号

8 要造

可

ह ํㅗㅇ

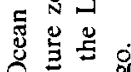

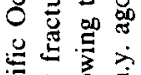

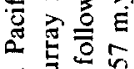

동 $\frac{2}{2} \frac{2}{0}$

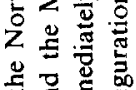

Е ํㅡㄹ है

ธิ

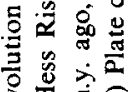

记

妿

윤 0 응

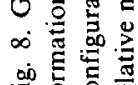

证要 
transform boundary (Chinook trough), and on the east by the northeast-trending Kula-North Farallon spreading center.

The Chinook plate was bounded on the west by a slow-spreading Pacific-Chinook ridge (now the southern Emperor trough), to the south by the Mendocino transform, a moderately-spreading Chinook-North Farallon ridge to the east, and to the north the Chinook-Kula spreading center. This new configuration also involved a change in the tectonic character of the North Farallon-South Farallon boundary from a left-lateral strike-slip fault to a north-south spreading ridge.

The five plate configuration entails four triple junctions (Fig. 8d). To the west, the Kula-Chinook-Pacific triple junction was a ridge-ridge-ridge configuration migrating northward from the west end of the Chinook trough. Southeast of the Chinook plate, the Chinook-North FarallonPacific triple junction was a ridge-fault-fault configuration moving slowly east-northeast as the oblique trends in the Mendocino boundary were active. The Kula-North Farallon-Chinook ridge-ridge-ridge triple junction migrated to the northeast and generated the magnetic anomalies of the Great Magnetic Bight. The Pacific-North Farallon-South Farallon triple junction had fault-ridge-ridge character and migrated slowly northward as the Pacific-South Farallon ridge extended its length.

Once created, the Chinook plate continued to grow (Fig. 8e and $\mathrm{f}$ ) until the subduction of the Chinook-Kula spreading center. At that time (anomaly 22, 50 m.y.), opening across the Emperor trough ceased, the Chinook plate became welded to the Pacific plate, the North and South Farallon plates were apparently reunited, and the Pacific-Farallon ridge became the only spreading center in the North Pacific. The age of ridge subduction at the Aleutian trench has been estimated to be as old as 53 m.y. ago based on magnetic anomaly data [63], and as young as 30 m.y. ago, based on Aleutian Island geology [64]. We would place this event as occurring when the Surveyor fracture zone changed trend and became parallel to the Mendocino fracture zone, signifying that both fracture zones now commonly reflect Pacific-Farallon relative motion. This site is, un- fortunately, not well-constrained by bathymetric data, but appears to occur near $153^{\circ} \mathrm{W}, 44^{\circ} \mathrm{N}$ $[6,10]$. Another indicator of this reorganization is the termination of the oblique Mendocino trends at the east end of the diamond-shaped region. The oldest anomaly south of the Surveyor that reflects this reorientation is anomaly 22 [10], $50.5 \mathrm{~m}$.y. old [33]. This result is in general agreement with that of Byrne [63] but not with DeLong et al. [64]. The Chinook plate thus existed as a separate lithospheric unit for 32 m.y. from 82 to 50 m.y. ago.

\section{Ramifications of the Chinook plate hypothesis}

Recognition of the Chinook and North Farallon plates as separate structural units that existed for over $30 \mathrm{~m} . \mathrm{y}$. resolves most of the difficult questions in the Late Cretaceous geological evolution of the North Pacific. The sequence of events proposed here holds a number of ramifications, three of which are discussed below: the age of the Kula plate, Pacific basin events, and circum-Pacific volcanic and tectonic events.

\subsection{The Kula plate}

A reorganization of lithospheric plates 82 m.y. ago, caused by the subduction of far North Pacific spreading centers, resulted in the formation of the Kula and Chinook plates. The Kula plate is, therefore, not the geological descendent of the northwestern plate of the Jurassic/Early Cretaceous North Pacific triple junction (the Bering plate of Fig. 8). Recognition of this fact obviates the necessity of postulating a sudden southerly shift of that old triple junction to account for the Great Magnetic Bight, an awkward point of prior reconstructions [22-24]. This conclusion is similar to that reached by Woods and Davies [28] and conforms more closely to the original concept of the Kula plate set forth by Grow and Atwater [65].

\subsection{Pacific basin tectonic activity}

The two periods of plate reorganization in the North Pacific, 82 and $50 \mathrm{~m} . \mathrm{y}$. ago, both corre- 
spond to periods of enhanced volcanic activity. Widespread evidence for volcanic activity in the Cretaceous has been recognized for many years $[14,66,67]$. Recent work has demonstrated that the Cretaceous volcanism occurred in two distinct episodes, one beginning $110 \mathrm{~m} . \mathrm{y}$. ago and another 80 m.y. ago, each lasting for about 15 m.y. [26]. The younger of these episodes included the formation of and continuing activity from many of the linear island and seamount chains of the western Pacific, as well constructional volcanism atop some of the older plateaus $[26,67]$.

The pulse of volcanic activity that occurred in the Pacific basin during early Eocene time is not as well documented as either the older Cretaceous or younger Neogene episodes. Eocene basalts have been recovered from seamounts or islands in the Line Islands [68], the Marshall Islands [69], and at DSDP Site 292 in the Philippine Sea [70]. The marine sedimentary record documenting Eocene volcanic activity is also limited. Volcanic input to sedimentary sections in amounts greater than normal have been measured in DSDP cores from Hess rise [38] and from the Nauru Basin where the maximum Cenozoic volcanic input occurred 49-51 m.y. ago [71].

The general northward motion of the Pacific plate changed direction in Late Cretaceous time and again in the early Tertiary. Two similar accounts of these motions have been constructed from the history of sediment accumulation in drill sites that have passed beneath the equatorial high-productivity zone. Van Andel et al. [72] have suggested that northward motion ongoing since about 78 m.y. ago changed to a west-northwest trend at $50 \mathrm{~m}$.y. ago. Lancelot [73] postulated an age of $40 \mathrm{~m} . \mathrm{y}$. ago for this younger direction change, and $70 \mathrm{~m} . \mathrm{y}$. ago for the Cretaceous change from west-northwest to north-northwest motion. Both authors believe the age of the Eocene change is coeval to that of the trend change in the Hawaii-Emperor seamount chain.

The timing of the older change (older than 78 m.y., or 70 m.y.) is not well constrained and may not be significantly different than that of the 82-m.y. ago plate reorganization described above. The timing and synchroneity of the several Eocene events, however, remains open to discussion. But- ler and Coney [74] recently summarized the problem concerning the relation, if any, between the Eocene changes in the North Pacific tectonic regime. The Hawaii-Emperor bend records a $60^{\circ}$ change in the direction of motion of the Pacific plate over the magma melting point in the asthenosphere that occurred about 42 m.y. ago [75]. A regional change of this magnitude would be expected to register along the boundaries of the Pacific plate. The northeast Pacific magnetic anomalies and fracture zones reflect a significant reorganization at the time of anomaly 23 to 21 , 48-52 m.y. ago [33]. Butler and Coney [74] attempted to resolve the difference in ages but it still seems likely that the two events are separated in age by several million years. The demise of a separate Chinook plate correlates with the $50-\mathrm{m}$.y.old ridge and fracture zone reorganization and probably not with the Hawaii-Emperor bend as presently dated.

The early Eocene is also a time of changes in plate motions in the South Pacific. Australia began to move rapidly north from Antarctica [76] beginning the formation of the circumpolar ocean. Cande et al. [54] document a reorganization of plate boundaries in the southeast Pacific at anomaly 21 time. There, ridge jumping caused a large piece of the Pacific plate to become welded to the Antarctic plate. This process also left a scar in the lithosphere, the Hudson trough [54], which is similar bathymetrically to the Chinook trough.

\subsection{Circum-Pacific tectonics}

Volcanic activity along the North Pacific island arcs would be expected to reflect the formation and subduction of the Kula plate, but only fragmentary information exists about the Mesozoic history of the Aleutian-Bering region. It has been suggested that the Aleutian trench and ridge formed in the later part of the Cretaceous or earliest Tertiary time and isolated the Aleutian basin of the Bering Sea [77]. The east-west transform in the Bering-Farallon ridge (Fig. 8a) may have localized the formation of the trench, thus entrapping the Mesozoic magnetic anomalies now found to the north $[24,61]$. A similar origin has been suggested for the Philippine trench sys- 
tem [78]. Aleutian volcanism continued, eventually ending with a large outpouring in the early or middle Eocene. Following the Eocene activity a quiet period marked by uplift and erosion occurred. A series of plutons were emplaced in midMiocene time, followed by late Miocene to Recent volcanism $[64,77,79]$.

This volcanic history agrees with the tectonic sequence outlined above. Aleutian subduction may have started in the Late Cretaceous, but volcanic activity would have increased markedly as the Kula-Chinook ridge approached the trench during the Paleocene and reached a maximum at some later time when the axial magma chamber lay beneath the Aleutian arc. The main body of the Aleutian ridge was formed by voluminous submarine volcanism beginning in the Paleocene and concluding during the middle Eocene [80,81]. When the Chinook plate became welded to, and began moving west with, the Pacific plate, the northward component of subduction would have been greatly reduced resulting in an eventual reduction of Aleutian volcanic activity and subsequent isostatic rebound of the Aleutian ridge. Younger pulses of volcanic activity may correspond to the Neogene volcanic episodes documented elsewhere [82].

Between about 105 and 82 m.y. ago the Farallon plate appears to have been divided into northern and southern portions along the Mendocino fracture zone along which about $60 \mathrm{~mm} / \mathrm{yr}$ of left-lateral motion was occurring. Prior to 82 m.y. ago Farallon-American convergence was, therefore, much greater south of the Mendocino fault than north of it; the Mendocino-American plate intersection would have been near the Late Cretaceous equator. As a result of the formation of the Chinook plate and the Chinook-North Farallon ridge, relative motion across the Mendocino fracture zone changed to slow opening (Table 1), causing the North Farallon plate to increase its eastward motion by $60 \mathrm{~mm} / \mathrm{yr}$ and its northward motion by $17 \mathrm{~mm} / \mathrm{yr}$.

These interactions of the Farallon and American plates may explain the much more obvious development of Mesozoic subduction-related magmatic features in South America than in North America [83-85]. Furthermore, the sudden in- crease in North Farallon-North America convergence $82 \mathrm{~m} . \mathrm{y}$. ago coincides with the onset of the Laramide orogeny, which began in the Late Cretaceous and ended in mid-Eocene time. Upper Cretaceous plutons are common in western North America, as are Eocene volcanic masses. The onset and cessation of the Laramide orogeny have been attributed to significant reorganizations of plate movements occurring at those times [86,87]. The changes in plate motions described here-especially the increase in eastward motion of the North Farallon plate 82 m.y. ago-are of the proper age and magnitude to be the determining factor for the Laramide orogeny.

As Farallon-American interaction progressed from 82 to 50 m.y. ago, the NFAR-SFAR-NAM triple junction, probably a trench-trench-ridge junction, would have migrated to the north. This migration should have resulted in a south-to-north progression of uplift and volcanism of Laramide age in western North America along the approximate latitudes of Mexico.

\section{Some tests of the Chinook plate hypothesis}

The sequence of events proposed here predicts ages and structures of parts of the seafloor that could be verified by geophysical surveys. Probably the most critical area to examine is the region lying east of the northern Emperor trough. Bathymetric and magnetic anomaly trends in this area should reflect the proposed history of oblique opening followed by a rapid reorientation to a system of generally east-west ridges and northsouth transforms. We would expect an ensuing history of small ridge jumps healing lesser offsets and lengthen the ridge segments, similar to the sequence recorded by the closely spaced data east of $180^{\circ}$.

A second place where pertinent data could be obtained is the site of the original Chinook plate as created 82 m.y. ago (Fig. 8). Crust in this area once belonged to the Farallon plate and thus should be 82 to perhaps 110 m.y. ago and created by approximately easterly or northeasterly spreading. The topographic grain in this region is consistent with crust generated by easterly seafloor 
spreading [88], but basement ages are unknown.

Finally, improved bathymetric and magnetic maps of the Emperor trough and parts of the Mendocino and Surveyor fracture zones would serve to confine more rigorously the conclusions we have drawn from existing information.

\section{Summary}

An evaluation of the primary bathymetric and magnetic data from the central North Pacific, especially the trends of fracture zones, reveals the existence of a small plate, the Chinook plate, which grew to occupy the region bounded by the Emperor trough, Mendocino fracture zone, and the Great Magnetic Bight. Recognition of the Chinook plate allows a Late Cretaceous to early Tertiary history of the North Pacific to be formulated that is simpler than prior postulations and explains all the major geologic structures of the region. A further consequence of the proposed history is that, from perhaps 105 to $50 \mathrm{~m}$.y. ago, the Farallon plate was divided into northern and southern sections along the eastern extension of the Mendocino fracture zone. The sequence of events began $118 \mathrm{~m} . y$. ago at the time of anomaly M-0. Three northwest Pacific spreading centers radiated from a triple junction where the Pacific, Farallon, and a third northwestern plate, which we have called the Bering plate, come together. The Pacific-Farallon ridge is offset $350 \mathrm{~km}$ left-laterally, along the Mendocino fracture zone, and a somewhat lesser amount dextrally about $1000 \mathrm{~km}$ to the north, along a trend extending northeast from Shatsky rise. By 107 m.y. ago volcanic outpourings along the ridge segment between the Shatsky and Mendocino fracture zones had formed Hess Rise. At this time the spreading center south of the Mendocino jumped eastward, creating the Murray fracture zone with its $750 \mathrm{~km}$ offset. Slow spreading north of the Mendocino and faster spreading south of it caused left-lateral motion across its eastern extension, thus dividing the Farallon plate.

By 83 m.y. ago the Pacific-North Farallon ridge was in the position now approximated by the Emperor trough. The Pacific-North Farallon-
Bering triple junction lay $3300 \mathrm{~km}$ northwest of the Mendocino fracture zone at the SiberianAlaskan continental margin. Ensuing subduction of most of the remaining portions of the Bering plate and Bering-Pacific and Bering-North Farallon ridges resulted in the creation of subduction zones along the western and northern margins of the Pacific and North Farallon plates. This addition of sinking slabs to those plates caused a major change in the plate motions $82 \mathrm{~m} . \mathrm{y}$. ago. The Pacific plate began to move more to the northwest, but the North Farallon plate responded by breaking into three plates, a smaller North Farallon moving much more rapidly towards the east, the new Kula, and the Chinook plates.

The Chinook trough is the scar left by the initiation of spreading along the Chinook-Kula ridge. The Emperor trough was the divergent western boundary of both new plates, and the Mendocino fracture zone was the southern boundary of the growing Chinook plate. This new plate configuration was stable; for $32 \mathrm{~m} . \mathrm{y}$. the Chinook plate grew by spreading along three sides, and the Kula plate moved rapidly north and was subducted at the Aleutian trench faster than it was created, causing the eventual subduction of the Kula-Chinook ridge. This event which occurred about 50 m.y. ago terminated the existence of the Chinook plate as a separate plate; it became welded to the Pacific plate at the Emperor trough. The two sections of the Farallon plate joined, and the Pacific-Farallon ridge became the sole North Pacific spreading center and reorganized to a more east-west relative motion.

This history, with its significant changes at 82 and 50 m.y. ago, fits well with our information on other volcano-tectonic events in both the Pacific basin and circum-Pacific regions, especially the history of Aleutian volcanism and the onset and demise of the Laramide orogeny.

\section{Acknowledgements}

A central point in our discussion is that the several east-west segments of the Chinook trough are a lithospheric scar resulting from the cracking of the Farallon plate and the onset of north-south 
seafloor spreading there. This basic idea was developed by Barry Erickson of the ESSA Pacific Oceanographic Laboratory (now NOAA Pacific Marine Environmental Laboratory) during 1968 and 1969, in conjunction with Fred Naugler and others then at POL. The data shown in Fig. 3 were compiled by Erickson. The decision of NOAA in about 1970 to alter program priorities and the untimely deaths of both Naugler and Erickson kept this work from being published in more than abstract form.

This work was completed while the senior author was on sabbatical leave at the School of Oceanography, Oregon State University, and that organization is acknowledged for its support.

The authors wish to thank the Branch of Pacific Geology of the U.S. Geological Survey, Menlo Park, California, for invitations to join the $R / V$ "S.P. Lee" on its cruise from Ponapé, Caroline Islands, to Dutch Harbor, Alaska, in June and July of 1982. We appreciate the efforts of Dave Clague and Andy Stevenson, co-chief scientists, on our behalf. They and the remainder of the scientific party provided a variety of stimulating discussions about our concept of the Chinook paleoplate. D.W. Scholl, and K.D. Klitgord reviewed the manuscript and provided a number of helpful comments and suggestions for improvement.

\section{References}

1 A.D. Raff and R.G. Mason, Magnetic survey off the west coast of North America $40^{\circ} \mathrm{N}$ latitude to $52^{\circ} \mathrm{N}$ latitude, Geol. Soc. Am. Bull. 72, 1267-1270, 1961.

2 D.J. Elvers, C.C. Mathewson, R.E. Kohler and R.L. Moses, Systematic Ocean Surveys by the USC \& GSS "Pioneer" 1961-1963, ESSA Operational Data Rep. C\&GS DR-1, 19 pp., 1967.

3 G. Peter, Magnetic anomalies and fracture pattern in the northeast Pacific Ocean, J. Geophys. Res. 71, 5365-5374, 1966.

4 D.E. Hayes and J.R. Heirtzler, Magnetic anomalies and their relation to the Aleutian island arc, J. Geophys. Res. 73, 4637-4646, 1968.

5 B.H. Erickson and P.J. Grim, Profiles of magnetic anomalies south of the Aleutian island arc, Geol. Soc. Am. Bull. 80, 1387-1390, 1969.

6 G. Peter, B.H. Erickson and P.J. Grim, Magnetic structure of the Aleutian Trench and northeast Pacific basin, in: The Sea, 4, Part II, New Concepts of Sea Floor Evolution, A.E.
Maxwell, ed., pp. 191-222, Wiley-Interscience, New York, N.Y., 1970

7 D.E. Hayes and W.C. Pitman, III, Magnetic lineations in the North Pacific, in: Geological Investigations of the North Pacific, J.D. Hays, ed., Geol. Soc. Am. Mem. 126, 291-314, 1970.

8 P.J. Grim and B.H. Erickson, Fracture zones and magnetic anomalies south of the Aleutian trench, J. Geophys. Res. 74, 1488-1494, 1969.

9 W.C. Pitman, III and D.E. Hayes, Sea-floor spreading in the Gulf of Alaska, J. Geophys. Res. 73, 6571-6580, 1968.

10 T. Atwater and H.W. Menard, Magnetic lineations in the northeast Pacific, Earth Planet. Sci. Lett. 7, 455-450, 1970.

11 A. Malahoff and D.W. Handschumacher, Magnetic anomalies south of the Murray fracture zone: new evidence for a secondary sea-floor spreading center and strike-slip movement, J. Geophys. Res. 76, 6265-6275, 1971.

12 F.P. Naugler and J.M. Wageman, Gulf of Alaska: magnetic anomalies, fracture zones, and plate interactions, Geol. Soc. Am. Bull. 84, 1575-1584, 1973.

13 H.W. Menard, Deformation of the northeastern Pacific basin and the west coast of North America, Geol. Soc. Am. Bull. 64, 1149-1198, 1955.

14 H.W. Menard, Marine Geology of the Pacific, 271 pp., McGraw-Hill, New York, N.Y., 1964.

15 H.W. Menard, Extension of northeastern Pacific fracture zones, Science 155, 72-74, 1967.

16 A. Malahoff and G.P. Woollard, Magnetic surveys over the Hawaiian Islands and their geologic implications, Pacific Sci. 20, 265-311, 1966.

17 F.P. Naugler and B.H. Erickson, Murray fracture zone: westward extension, Science 161, 1142-1145, 1968.

18 D.K. Rea, Changes in structure and trend of fracture zones north of the Hawaiian ridge and relation to sea-floor spreading, J. Geophys. Res. 75, 1421-1430, 1970.

19 B.H. Erickson, F.P. Naugler and W.H. Lucas, Emperor fracture zone: a newly discovered feature in the central North Pacific, Nature 255, 53-54, 1970.

$20 \mathrm{~S}$. Uyeda and V. Vacquier, Geothermal and geomagnetic data in and around the island arc of Japan, in: The Crust and Upper Mantle of the Pacific Area, L. Knopoff, C.L. Drake and P.J. Hart, eds., Am. Geophys. Union, Geophys. Monogr. 12, 349-366, 1968.

21 D.E. Hayes and W.C. Pitman, III, Magnetic lineations in the northwest Pacific (abstract), EOS 50, 189, 1969

22 R.L. Larson and C.G. Chase, Late Mesozoic evolution of the western Pacific Ocean, Geol. Soc. Am. Bull. 83, $3627-3644,1972$

23 T.W.C. Hilde, N. Isezaki and J.M. Wageman, Mesozoic sea-floor spreading in the North Pacific, in: The Geophysics of the Pacific Ocean Basin and its Margin, G.H. Sutton, M.H. Manghnani and R. Moberly, eds., Am. Geophys. Union, Geophys. Monogr. 19, 205-226, 1976.

24 T.W.C. Hilde, S. Uyeda and L. Kroenke, Evolution of the western Pacific and its margin. Tectonophysics 38, 145-164, 1977.

25 E. Farrar and J.M. Dixon, Early Tertiary rupture of the 
Pacific plate: $1700 \mathrm{~km}$ of dextral offset along the Emperor trough-Line Islands lineament, Earth Planet. Sci. Lett. 53, 307-322, 1981.

26 D.K. Rea and T.L. Vallier, Two Cretaceous volcanic episodes in the western Pacific Ocean, Geol. Soc. Am. Bull. 94 (in press).

27 R.G. Gordon, Paleomagnetic test of the Emperor fracture zone hypothesis, Geophys Res. Lett. 9, 1283-1286, 1982.

28 M.T. Woods and G.F. Davies, Late Cretaceous genesis of the Kula plate, Earth Planet. Sci. Lett. 58, 161-166, 1982.

29 B.H. Erickson, D.K. Rea and F.P. Naugler, Chinook trough: A probable consequence of north-south sea-floor spreading (abstract), EOS 50, 633, 1969.

30 T.E. Chase, H.W. Menard, and J. Mammerickx, Bathymetry of the North Pacific Ocean, 10 sheets, Scripps Institution of Oceanography, La Jolla, Calif., 1972.

31 W.C. Pitman, III, R.L. Larson and E.M. Herron, Magnetic lineations of the oceans, Geol. Soc. Am. Chart Ser., 1974.

32 K.J. Drummond, C. Nishiwaki, J. Corvalán, H.F. Doutch and C. Craddock, Plate Tectonics Map of the Circum-Pacific Region, American Association of Petroleum Geologists, Tulsa, Okla., 1982.

33 W.B. Harland, A.V. Cox, P.G. Llewellyn, C.A.G. Pickton, A.G. Smith and R. Walters, A Geologic Time Scale, 3rd ed., Cambridge University Press, Cambridge (in press).

34 S. Stein, Intraplate seismicity on bathymetric features: the 1968 Emperor trough earthquake, J. Geophys. Res. 84, 4763-4768, 1979.

35 T.L. Valier, personal communication, 1982.

36 H.G. Greene, Geophysical observations taken underway on "Glomar Challenger", Leg 55, in: E.D. Jackson, I. Koisumi et al., Initial Reports of the Deep Sea Drilling Project 55, $789-800,1980$.

37 G.B. Dalrymple, H.G. Greene, B.D. Ruppel, T.E. Bear, and D.A. Clague, Pre Leg-55 site survey geophysical data from R / 'S.P. Lee' cruise LEE8-76-NP, in: E.D. Jackson, I. Koisumi et al., Initial Reports of the Deep Sea Drilling Project 55, 801-843, 1980.

38 T.L. Vallier, D.K. Rea, W.E. Dean, J. Thiede and C.G. Adelseck, The geology of Hess rise, central North Pacific Ocean, in: J. Thiede, T.L. Vallier et al., Initial Reports of the Deep Sea Drilling Project 62, 1031-1072, 1981.

39 H.R. Stevens, Jr., RP-1-OC-71 Northeast Pacific Geophysical Survey NOAA Tech. Rep. ERL 232-POL 10, 91 pp., 1972.

40 D.K. Rea, Magnetic anomalies along fracture zones, Nature Phys. Sci. 236, 58-59, 1972.

41 A. Malahoff, W.E. Strange and G.P. Woollard, Molokai fracture zone: Continuation west of the Hawaiian Ridge, Science 153, 521-522, 1966.

42 A. Malahoff and G.P. Woollard, Magnetic and tectonic trends over the Hawaiian Ridge, in: The Crust and Upper Mantle of the Pacific Area, L. Knopoff, C.L. Drake and P.J. Hart, eds., Am. Geophys. Union, Geophys. Monogr. 12, 241-276, 1968.

43 W.C. Pitman, III, E.M. Herron and J.R. Heirtzler, Magnetic anomalies in the Pacific and sea floor spreading, $J$. Geophys. Res. 73, 2069-2085, 1968.
44 W.H. Lucas and R.R. Ulhorn, Bathymetric and magnetic data from the Northeast Pacific $40^{\circ}$ to $58^{\circ} \mathrm{N}, 125^{\circ}$ to $160^{\circ} \mathrm{W}$, NOAA Tech. Rep. ERL 258-POL 15, 9 pp., 1973.

45 P. Lonsdale and K.D. Klitgord, Structure and tectonic history of the eastern Panama Basin, Geol. Soc. Am. Bull. 89, 981-999, 1978.

46 K.D. Klitgord and J. Mammerickx, Northern East Pacific Rise: Magnetic anomaly and bathymetric framework, J. Geophys. Res. 87, 6725-6750, 1982.

47 R. Batiza and C.G. Chase, Miocene spreading centre south of Isla Guadalupe, Nature 289, 787-789, 1981.

48 R.L. Larson, S.M. Smith, and C.G. Chase, Magnetic lineations of Early Cretaceous age in the western equatorial Pacific Ocean, Earth Planet. Sci. Lett. 15, 315-319, 1972.

49 K. Tamaki, M. Joshima and R.L. Larson, Remanent Early Cretaceous spreading center in the central Pacific basin, J. Geophys. Res. 84, 4501-4510, 1979.

50 E.L. Winterer, Anomalies in the tectonic evolution of the Pacific, in: The Geophysics of the Pacific Ocean Basin and its Margin, G.H. Sutton, M.H. Manghnani and R. Moberly, eds., Am. Geophys. Union, Geophys. Monogr. 19, 269-278, 1976.

51 J.K. Weissel and A.B. Watts, Tectonic evolution of the Coral Sea basin, J. Geophys. Res. 84, 4572-4582, 1979.

52 J.G. Sclater, R.N. Anderson, and M.L. Bell, Elevation of ridges and evolution of the central eastern Pacific, J. Geophys. Res. 76, 7888-7915, 1971.

53 D.K. Rea, Tectonics of the Nazca-Pacific divergent plate boundary, in: Nazca Plate: Crustal Formation and Andean Convergence, L.D. Kulm, J. Dymond, E.J. Dasch and D.M. Hussong, eds., Geol. Soc. Am. Mem. 154, 27-62, 1981.

54 S.C. Cande, E.M. Herron and B.R. Hall, The early Cenozoic tectonic history of the southeast Pacific, Earth Planet. Sci. Lett. 57, 63-74, 1982.

55 T.L. Vallier, W.E. Dean, D.K. Rea and J. Thiede, Geologic evolution of Hess rise, central North Pacific Ocean. Geol Soc. Am. Bull. 94 (in press).

56 A.B. Watts, J.H. Bodine and N.M. Ribe, Observations of flexure and the geological evolution of the Pacific Ocean basin, Nature 283, 532-537, 1980.

57 D.K. Rea and F.P. Naugler, Musicians seamount province and related crustal structures north of the Hawaiian Ridge, Mar. Geol. 10, 89-111, 1971.

58 J. Mammerickx, E. Herron and L. Dorman, Evidence for two fossil spreading ridges in the southeast Pacific, Geol Soc. Am. Bull. Part 1, 91, 263-271, 1980.

59 R.A. Duncan and D.A. Clague, Linear volcanism on the Pacific plate, in: The Ocean Basins and Margins, The Pacific, A.E.M. Nairn and F.G. Stehli, eds., Plenum Press, New York, N.Y. (in preparation).

60 R.L. Larson, Late Jurassic and Early Cretaceous evolution of the western central Pacific Ocean, J. Geomag. Geoelectr. 28, 219-236, 1976.

61 A.K. Cooper, M.S. Marlow and D.W. Scholl, Mesozoic magnetic lineations in the Bering Sea marginal basin, J. Geophys. Res. 81, 1916-1934, 1976.

62 L.W. Kroenke and K. Nemoto, Marine geology of the Hess rise, 2. Basement morphology, sediment thickness, and 
structural geology, J. Geophys. Res. 87, 9259-9278, 1982.

63 T. Byrne, Late Paleogene demise of the Kula-Pacific spreading center, Geology 7, 341-344, 1979.

64 S.E. DeLong, P.J. Fox and F.W. McDowell, Subduction of the Kula ridge at the Aleutian trench, Geol. Soc. Am. Bull. 89, 83-95, 1978.

65 J.A. Grow and T. Atwater, Mid-Tertiary tectonic transition in the Aleutian arc, Geol. Soc. Am. Bull. 81, 3715-3722, 1970.

66 E.D. Jackson and S.O. Schlanger, Regional synthesis, Line Islands chain, Tuamotu Island chain, and Manihiki Plateau, central Pacific Ocean, in: S.O. Schlanger, E.D. Jackson et al., Initial Reports of the Deep Sea Drilling Project 33, 915-927, 1976.

67 S.O. Schlanger, H.C. Jenkyns and I. Premoli Silva, Volcanism and vertical tectonics in the Pacific basin related to global Cretaceous transgressions, Earth Planet. Sci. Lett. $52,435-449,1981$.

68 J.A. Haggerty, S.O. Schlanger and I. Premoli Silva, Late Cretaceous and Eocene volcanism in the southern Line Islands and implications for hot spot theory, Geology 10 , 433-437, 1982.

69 H. Ladd, E. Ingerson, R.C. Townsend, M. Russell and H.K. Stephenson, Drilling on Eniwetok Atoll, Marshall Islands, Am. Assoc. Pet. Geol. Bull. 37, 2257-2280, 1953.

70 D.E. Karig, J.C. Ingle, Jr. et al., Initial Reports of the Deep Sea Drilling Project 31, 927 pp., U.S. Government Printing Office, Washington, D.C., 1975.

71 D.K. Rea and J. Thiede, Mesozoic and Cenozoic mass-accumulation rates of major sediment components in the Nauru Basin, western equatorial Pacific, in: R.L. Larson, S.O. Schlanger et al., Initial Reports of the Deep Sea Drilling Project 61, 549-555, 1981.

72 Tj.H. van Andel, G.R. Heath and T.C. Moore, Jr., Cenozoic History and Paleoceanography of the Central Equatorial Pacific Ocean, Geol. Soc. Am. Mem. 143, 134 pp., 1975.

73 Y. Lancelot, Relations entre évolution sedimentaire et tectonique de la Plaque pacifique depuis la Cretacee inferieur, Geol. Soc. Fr. Mem. N.S., 134 pp., 1978.

74 R.F. Butler and P.J. Coney, a revised magnetic polarity time scale for the Paleocene and early Eocene and implications for Pacific plate motion, Geophys. Res. Lett. 8, 301-304, 1981.

75 D.A. Clague, G.B. Dalrymple and R. Moberly, Petrography and $\mathrm{K}$-Ar ages of dredged volcanic rocks of the western Hawaiian ridge and southern Emperor Seamount chain, Geol. Soc. Am. Bull. 86, 991-998, 1975.
76 J.K. Weissel, D.E. Hayes and E.M. Herron, Plate tectonics synthesis: The displacements between Australia, New Zealand and Antarctica since the Late Cretaceous, Mar. Geol. 25, 231-277, 1977.

77 D.W. Scholl, E.C. Buffington and M.S. Marlow, Plate tectonics and the structural evolution of the Aleutian-Bering Sea region, in: Contributions to the Geology of the Bering Sea Basin and Adjacent Regions, R.B. Forbes, ed., Geol. Soc. Am. Spec. Paper 151, 1-31, 1975.

78 S. Uyeda and A. Miyashiro, Plate tectonics and the Japanese Islands: a synthesis, Geol. Soc. Am. Bull. 85, 1159-1170, 1974.

79 M.S. Marlow, D.W. Scholl, E.C. Buffington and T.R. Alpha, Tectonic history of the central Aleutian arc, Geol. Soc. Am. Bull. 84, 1555-1574, 1973.

80 D.W. Scholl, T.L. Vallier, and A.J. Stevenson, First-order effects of Tertiary interactions between the Pacific and North American plates-evidence from the Aleutian ridge (abstract), EOS 63, 913, 1982.

81 D.W. Scholl, T.L. Vallier and A.J. Stevenson, Arc, forearc, and trench sedimentation and tectonics; Amlia corridor of the Aleutian Ridge, in: Continental Margin Processes, J.S. Watkins and C.E. Drake, eds., Am. Assoc. Pet. Geol. Mem. 34 (in press).

82 J.P. Kennett, A.R. McBirney and R.C. Thunell, Episodes of Cenozoic volcanism in the circum-Pacific region, J. Volcanol. Geotherm. Res. 2, 145-163, 1977.

83 D.E. James, Plate tectonic model for the evolution of the central Andes, Geol. Soc. Am. Bull. 82, 3325-3346, 1971.

$84 \mathrm{~J}$. Frutos, Andean tectonics as a consequence of sea-floor spreading, Tectonophysics 72, T21-T32, 1981.

85 M.A. Bussel, Timing of tectonic and magnatic events in the central Andes of Peru, J. Geol. Soc. London 140, 279-286, 1983.

86 P.J. Coney, Mesozoic-Cenozoic Cordilleran plate tectonics, in: Cenozoic Tectonics and Regional Geophysics of the Western Cordillera, R.B. Smith and G.P. Eaton, eds., Geol. Soc. Am. Mem. 152, 33-50, 1978.

87 W.R. Dickinson and W.S. Snyder, Plate tectonics of the Laramide orogeny, in: Laramide Folding Associated with Basement Block Faulting in the Western United States, V. Matthews, III, ed., Geol. Soc. Am. Mem. 151, 355-366, 1978.

88 F.P. Naugler and D.K. Rea, Abyssal hills and sea-floor spreading in the central North Pacific, Geol. Soc. Am. Bull. $81,3123-3128,1970$. 